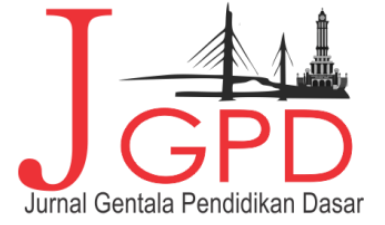

Research Article

\title{
Pengaruh Pendekatan Matematika Realistik Terhadap Prestasi dan Karakter Jujur Kelas III SDIT Al-Madinah Cibinong Bogor
}

\author{
Muhyani $^{1}$, Tyas Dian Lestari ${ }^{2}$, H.Mukhtar $^{3}$, Salati Asmahasanah ${ }^{4}$ \\ ${ }^{1}$ Mahasiswa PGMI Ibn Khaldun Bogor, ${ }^{23}$ Dosen Tetap Prodi PGMI Ibn Khaldun Bogor, Jawa Barat, \\ Indonesia
}

\section{Article Information}

Reviewed : Juli 20, 2019

Revised : Agustus 10, 2019

Available Online : Dec 1, 2019

\section{Keyword}

Realistic Mathematical

Approaches, Learning

Achievement and Honest

Character

\section{Corespondence}

e-mail :

yaniwongtegal@gmail.com

\section{ABSTRACT}

This research is to know the effect of realistic mathematical approaches on learning achievement and honest character in second grade at Al-Madinah Cibinong Bogor Elementary School. This research was the quantitative research with types of quasi-experimental research, the selection of subjects in the quasi-experimental type of Non Equivalent Control Group Design was deliberately chosen by researchers. Using 3 variables, namely the independent variable (X) and the dependent variable (Y1, Y2). Data collection techniques using research instruments are observation, test and documentation. This research resulted in an average data post-test experimental class of 96,4 and the average post-test control class 87,4 so that the obtained - $t$ count $>-t$ table $(-9,328>-7,211)$, it can be concluded that there are significant influenced of realistic mathematical approaches to achievement. Honest character observation data produced an experimental class average of 30,1 , and the average after the application of the control class learning was 20.3 so that the obtained -t count> $-t$ table ($42.121>-24.852)$, it can be concluded that there is significant effect of realistic mathematical approaches on learning achievement and honest character.

\section{PENDAHULUAN}

Salah satu masalah dalam pendidikan di Indonesia adalah lemahnya proses pembelajaran (Sanjaya : 2007). Mendidik artinya mengembangkan sikap atau afektif, mengajar mengembangkan pengetahuan atau kognitif, dan melatih artinya mengembangkan keterampilan para siswa serta seorang guru harus professional. (sukadi dalam Chan,F, Kurniawan,AR., dkk, 2019). Permasalahan pembelajaran tersebut tidak lepas dari kemampuan rendahnya kemampuan pemecahan masalah. Pada era revolusi industri 4.0 dan university 5.0 maka dibutuhkan keterampilan yang memadai termasuk pemecahan masalah bagi peserta didik (Kurniawan, Noviyanti, dan Arsil, 2019).

Salah satu komponen yang memegang peranan penting dalam kelangsungankegiatan pembelajaran adalah guru. Oleh karena itu, seorang guru dituntut untukbersifat sebagai artis 
yaitu guru harus dapat berperan dimuka kelas layaknyaseorang artis, dan sebagai scientist yaitu dalam menghadapi masalah-masalahyang timbul di dalam kelas guru dapat memecahkan masalah tersebut dengan cara ilmiah. (Sabrani, Rahman dan Asmahasah, 2017)

Pemecahan masalah merupakan jantung pembelajaran dalam mengatasi permasalahan matematika. Sementara tantangan matematika adalah elemen inti dari setiap proses pendidikan. Pemecahan masalah sebagai suatu usaha mencari jalan keluar dari suatu kesulitan guna mencapai suatu tujuan yang tidak begitu segera dapat dicapai. Sehingga diperlukan pendidik yang profesional dan memiliki keahlian dalam menangani pemecahan masalah matematika, agar membantu siswa menjadi pemecahan masalah yang lebih baik. (Sarbiyono : $2006: 164)$

Matematika merupakan salah satu cabang ilmu yang dapat meningkatkan kualitas sumber daya manusia, di samping itu matematika juga merupakan faktor pendukung dalam laju perkembangan dan persaingan di berbagai bidang.Matematika lahir karena dorongan kebutuhan manusia dengan bantuan matematika banyak peristiwa atau kejadian alam semesta ini yang dapat dipelajari. (Yantoro, 2017). Menurut Ruseffendi menyatakan bahwa matematika adalah ilmu deduktif yang tidak menerima pembuktian secara induktif. Sedangkan hakikat matematika menurut Soedjadi yaitu memiliki objek tujuan abstrak, bertumpu pada kesepakatan dan pola pikir yang deduktif ( Heruman, 2012 :1)

The education in the New Global Economy (EDGE) Ohio Departemen of Education (2008 : 3) didalam penelitian nya menyatakan diperoleh 10 kemampuan teratas yang dibutuhkan siswa untuk persiapan menghadapi persaingan ekonomi global, dua diantaranya yaitu (1) pemikiran kritis, keterampilan memecahkan masalah, dan pengetahuan terapan untuk hasil praktis dan (2) pemikiran inovatif dan kreatif.

Oleh karena itu diperlukan suatu bidang ilmu yang dapat mengembangkan kemampuan berfikir kritis, logis, dan kreatif. Salah satu bidang ilmu yang dapat mengembangkan kemampuan berfikir kritis, sistematis. Logis dan kreatif adalah matematika.

Salah satu tujuan umum diberikan matematika dijenjang persekolahan yaitu mempersiapkan siswa agar sanggup mengahadapi perubahan keadaan didalam kehidupan dan dunia yang selalu berubah dan berkembang memalui latihan bertindak atas dasar pemikiran secara logis, kritis, cermat, jujur dan efektif dan dapat menggunakan pola pikir matematis dalam kehidupan sehari-hari dan dalam mempelajari ilmu matematika. 


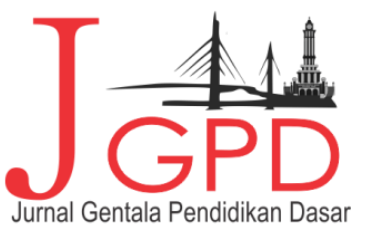

JURNAL GeNTALA PENDIDIKAN DASAR Vol.4 No 2 December 2019 Page 15I-I65 P-ISSN : 2614-7092, E-ISSN : 2621-S611

Available Online at: http://online-juurnal.unja.ac.id/index.php/gentala email : penyunting.jurnal.g-pgsd国unja.ac.id

Matematika sejak dulu memang dianggap sebagai mata pelajaran yang sulit dan menyeramkan bagi para siswa (Nagaswari dalam Astutu, Siswati, \& Setyawan, 2013) berdasarkan pada pemeringkatan Programme for International Student Assesment (PISA) terakhir, kemampuan literasi matematika siswa Indonesia sangat rendah, yaitu memduduki peringkat 61 dari 65 negara yang menjadi peserta (news.okezone.com) berdasarkan data dari UNESCO, mutu pendidikan Matematika di Indonesia berada pada peringkat 34 dari 38 negara yang diamati, walaupun hal itu tidak menampik prestasi siswa indonesia dibidang matematika pada berbagai ajang kompetisi dunia memberikan hasil yang baik.

Ada beberapa permasalahan dalam pembelajaran Matematika di Indonesia, diantaranya : (1) Pembelajaran yang diberikan di kelas hanya bergantung pada buku pegangan (1) proses belajar mengajar masih konvensional dan tidak bervariasi (3) belum menggunakan ICT dan lingkungan secara maksimal ( Yuani, 2013) (Anggraeni, 2012) terlepas dari itu semua, pada dasarnya permasalahan mengenai mengapa para siswa tidak memiliki kemampuan literasi Matematika yang baik kembali pada siswa itu sendiri, yaitu rendahnya motivasi belajar, walaupun tidak menampik bahwa faktor lain juga memiliki pengaruh yang cukup besar, seperti kurangnya literatur maupun kurang menariknya metode pengajaran guru.( Suhandi dan Sawitri, $2017: 2-3)$

Dalam dunia pendidikan masih banyak peserta didik yang merasa kesulitan, dalam mata pelajaran matematika, sampai peserta didik tidak menyukai pada mata pelajaran matematika, yang menurut mereka mata pelajaran tersebut sulit di mengerti maupun dipahami sehingga mereka tidak menyukai mata pelajaran tersebut. Karena tidak ketertarikan mereka terhadap pembelajaran matematika tersebut menghasilkan belajar matematika yang rendah

Dari berita online oke zone news, Margaret Puspitariani (2014), menulis dalam artikelnya bahwa salah satu bukti rendahnya Prestasi Matematika siswa Indonesia terlihat dari hasil Ujian Nasional beberapa tahun terakhir. Pada tahun 2010, sebanyak 35.567 atau 6,66 persen siswa SMP dan MTS di Jawa Timur dan 1.600 atau 20\% siswa di Balik Papan tidak lulus dalam UN. Penyebab ketidak lulusan itu terletak pada nilai-nilai Bahasa Indonesia dan Matematika yang kurang dari empat.Kondisi tersebut diperkuat hasil survey The National Center for Education Statistic (NCES) pada tahun 2003 tentang prestasi pelajar Indonesia. Data tersebut mengungkapkan, prestasi pelajar Indonesia berada di peringkat ke 39 dari 41 negara. Bahwa realitanya pelajaran matematika memang masih sulit untuk di mengerti setiap 


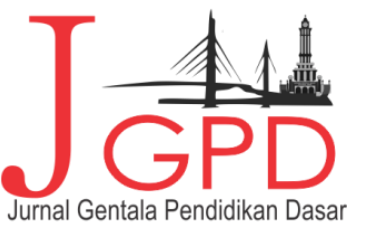

JURNAL GeNTALA PENDIDIKAN DASAR Vol.4 No 2 December 2019 Page 15I-I65 P-ISSN : 2614-7092, E-ISSN : 2621-S611

Available Online at: http://online-juurnal.unja.ac.id/index.php/gentala email : penyunting.jurnal.g-pgsd国unja.ac.id

peserta didik, sehingga berpengaruh kepada hasil tersebut yang membuat rendah dan sehingga mengakibatkan yang tidak lulus dalam UN, serta mempengaruhi data statistik pelajar di Indonesia yang menjadi turun.

Pendidikan di Indonesia masih dianggap sangat rendah terutama untuk pelajaran Matematika. Padahal matematika adalah pelajaran pokok yang diajarkan untuk sekolah dasar hingga perguruan tinggi.Iindikasi ini dapat dilihat dari masih rendahnya prestasi belajar siswa disetiap jenjang pendidikan. Ironisnya matematika termasuk pelajaran yang tidak disukai. Banyak siswa takut akan pelajaran matematika. Bagi mereka matematika seperti musuh yang menakutkan yang ingin sekali mereka hindari. Tidak sedikit siswa yang mengeluh dengan adanya pelajaran matematika.

Menurut Locke yang dikutip oleh Sujono (1998:8) dalam buku pengajaran matematika untuk sekolah menyatakan bahwa : "Matematika merupakan sarana untuk menanamkan kebiasaan menalar di dalam pikiran orang" Matematika merupakan pengetahuan yang eksak dan pasti sehingga langsung menuju sasaran dan dapat menyebabkan timbulnya disiplin dalam pikiran, sehingga jika matematika diajarkan dengan cara yang benar maka matematika dapat mengembangkan kemampuan berfikir dan menalar, untuk itulah seharusnya siswa memiliki keinginan yang tinggi dan senang untuk mempelajari matematika (Sirait, 2016 : 36)

Matematika sebenarnya merupakan mata pelajaran yang memiliki manfaat besar dalam perkembangan ilmu pengetahuan dan teknologi. Matematika juga memiliki manfaat besar dalam menyelesaikan berbagai masalah kehidupan sehari hari.( Ratumanan \& Laurens : 2016 :146)

Permasalahan dalam pembelajaran di atas, pada dasarnya disebabkan oleh pola mengajar guru yang kurang inovatif. Sejalan dengan hal tersebut, Suharta (2002) mengemukakan bahwa dalam pembelajaran matematika di SD seringkali urutan-urutan pembelajaran yang dilaksanakan oleh guru adalah : pendahuluan, menjelaskan, memberikan tugas. Siswa tidak diberikan kesempatan untuk menyampaikan pendapat, memberikan alasan, atau mendiskusikan perbedaan-perbedaan jawaban siswa. Akibatnya, pembelajaran matematika disekolah hanyalah bersifat hafalan dan bukan melatih pola pikir siswa, sehingga prestasi belajarnya pun menjadi rendah.

Mengacu pada uraian di atas, terdapat kesenjangan yang cukup tinggi antara harapan pembelajaran matematika dengan kenyataan dalam pelaksaan pembelajaran matematika yang mekanistis. Untuk mencapai peningkatan mutu pendidikan seperti yang diharapkan, guru 


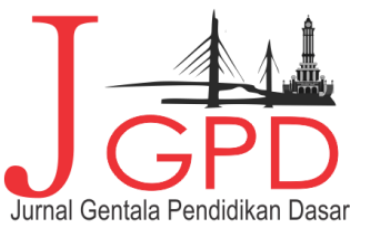

JURNAL GeNTALA PENDIDIKAN DASAR Vol.4 No 2 December 2019 Page 15I-I65 P-ISSN : 2614-7092, E-ISSN : 2621-S611

Available Online at: http://online-journal.unja.ac.id/index.php/gentala email : penyunting.jurnal.g-pgsd国unja.ac.id

perlu memperbaiki pola pembelajaran dan mengupayakan suatu inovasi dalam kegiatan pembelajaran. Salah satu pendekatan pembelajaran yang sesuai dengan hal tersebut adalah melalui penerapan pendekatan matematika realistik. Dalam penerapannya, pendekatan matematika realistik menggunakan masalah realistik, menggunakan model, menggunakan kontribusi siswa, terjadi interkasi dalam proses pembelajaran, menggunakan berbagai terori belajar yag relavan dan sebagainya

Sadra (2009) menyatakan bahwa gambaran umum dari pendekatan matematika realistik yaitu siswa tidak lagi diberikan penjelasan materi secara lengkap oleh guru, melainkan hanya diarahkan pada pemahaman materi berdasarkan pengalaman mereka mereka memecahkan masalah. Keterampilan pemecahan masalah matematika yang meningkat pada siswa yang memiliki pengaturan diri yang lebih tinggi agar berhasil dalam tantangan belajar (Supriatna, 2019).

Guru tidak lagi memaksa siswa untuk mengikuti cara berfikir yang dimiliki nya, tetapi harus memberi kesempatan kepada siswa untuk mengembangkan cara berfikir mereka sesuai dengan potensinya dan guru hanya berperan membantu serta mengarahkan cara berfikir siswa untuk memhami konsep melalui pertanyaan arahan (bukan memberikan secara langsung). Apabila hal ini dilatih secara terus menerus diduga akan meningkatkan prestasi belajar matematika Astuti dkk : 2013 : 2-3)

Pendekatan konvensional adalah sebuah bentuk interaksi melalui penerangan dan penuturan lisan dari guru kepada peserta didik. Dalam pelaksanaan konvensional untuk menjelaskan uraiannya, guru dapat menggunkan alat-alat bantu seperti gambar dan audio visual lainnya. Konvensional juga sebagai kegiatan memberikan informasi dengan kata-kata yang sering mengaburkan dan kadang-kadang ditafsirkan salah ( Taniredja dkk : 2011 : 45)

Salah satu pendekatan yang berpengaruh terhadap proses pembelajaran matematika yang menyenangkan yaitu pendekatan pembelajaran matematika realistik. Karena berbeda dengan pendekatan konvensonal, pendekatan matematika realistik sama artinya dengan Active Learning yang berpusat kepada siswa, siswa berperan aktif dalam pembelajaran sedangkan guru hanya membimbing dan mengontrol setiap pembelajaran. Pendekatan matematika realistik membuat pembelajaran lebih menyenangkan karena mengajak siswa untuk ikut serta dalam proses pembelajaran dan mengajak siswa memecahkan permasalahan.

Pendidikan Nasional berfungsi mengembangkan kemampuan dan membentuk watak serta peradaban bangsa yang bermartabat dalam rangka mencerdaskan kehidupan bangsa, 
yang bertujuan untuk berkembangnya potensi peserta didik agar menjadi manusia yang beriman dan bertaqwa kepada Tuhan Yang Maha Esa, berakhlak mulia, sehat, dan berilmu, cakap, kreatif, mandiri, jujur, dan menjadi warga negara yang demoktratis serta bertanggung jawab (Undang-Undang Nomor 20 tahun 2003)

Berdasarkan fungsi dan tujuan pendidikan nasional di atas, jelaslah bahwa hal tersebut berkaitan dengan pembentukan karakter peserta didik sehingga mampu bersaing, beretika, bermoral, sopan santun dan berakhak serta berinterasi dengan masyarakat.

Lembaga pendidikan sebagai tempat pembentukan karakter peserta didik dituntut untuk meningkatkan intensitas dan kualitas pelaksaannya Oleh karena itu, lembaga pendidikan sebagai wadah resmi pembinaan generasi muda diharapkan dapat meningkatkan peranan dalam pembentukan kepribadian peserta didik dan masyarakat.Untuk mencegah semakin parahnya krisis akhlak pada generasi muda, pendidikan karakter dapat diintegrasikan kedalam setiap mata pelajaran, termasuk mata pelajaran matematika. Pembelajaran matematika merupakan bagian integral dalam sistem pendidikan yang ada di sekolah dan diberikan mulai dari jenjang pendidikan dasar hingga pendidikan menengah bahkan pada pendidikan tinggi.

Disinilah kita pahami, mengapa ada kesengajaan antara praktik pendidikan denga karakter peserta didik. Bisa dikatakan, dunia pendidikan kita sedang memasuki masa-masa yang sangat pelik. Kekurangan anggaran pendidikan yang sangat besar disertai berbagai program trobosan sepertinya belum mampu memecahkan persoalan mendasar dalam dunia pendidikan, yakni bagaimana mencetak alumni pendidikan yang unggul, yang beriman, bertaqwa, profesional dan berkarakter, sebagaimana yujuan dari Pendidikan Nasional. Untuk mencapai tujuan tersebut maka perlu adanya penanaman karakter kejujuran. Dalam Humaidi (kejujuran) adalah sendi yang terpenting bagi tegaknya masyarakat, sebab dengan adanya kebenaran maka akan terciptanya rasa saling pengertian satu sama lain dalam masyarakat, dan tanpa adanya saling pengertian tidak akan terjadi saling tolong menolong, sedangkan bahasa diciptakan juga untuk saling pengertian ini, yang tanpa itu tidak mungkin terjadi kehidupan masyarakat.

Kejujuran dalam konteks pembangunan karakter disekolah menjadi sangat penting untuk menjadikan karakter peserta didik saat ini sebagai bekal mengarungi kehidupan dimasa yang akan datang. Karakter seperti itu dapat dilihat secara langsung didalam kelas, semisal ketika peserta didik melaksanakan proses pembelajaran maupun melaksanakan 


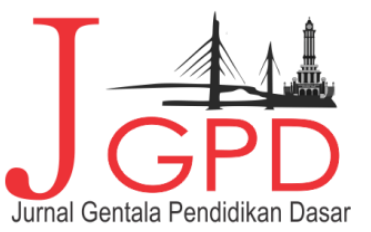

JURNAL GeNTALA PENDIDIKAN DASAR Vol.4 No 2 December 2019 Page 15I-I65 P-ISSN : 2614-7092, E-ISSN : 2621-S611

Available Online at: http://online-juurnal.unja.ac.id/index.php/gentala email : penyunting.jurnal.g-pgsd国unja.ac.id

ujian.Mencontek merupakan perbuatan yang mencerminkan peserta didik berbuat tidak jujur kepada diri, teman, orang tua, dan pendidiknya.

Bagi guru hal ini, mungkin menjadi tantangan baru, selain mencapai tujuan-tujuan pembelajaran yang bersifat kognitif yang sampai sekarang masih menjadi tugas yang cukup berat, terutama bagi guru-guru mata pelajaran umum, seperti matematika. (Dewi : 2015 : 117 118)

Berdasarkan uraian di atas penulismencoba menerapkan salah satu pendekatan pembelajaran yaitu matematika realistik untuk mengungkapkan apakah dengan pendekatan matematika realistik berpengaruh terhadap prestasi dan karakter jujur siswa pada materi pelajaran matematika.

Penulis memilih pendekatan ini karena pendekatan ini mengkondisikan siswa dalam mengaitkan kehidupan sehari-hari dan membuat siswa aktif yang diharapkan bisa membuat prestasi siswa dan kepribadian belajar siswa yang baik. Jika siswa semangat dalam mempelajari Matematika mereka tidak segan dalam mencari cara menyelesaikan persoalan matematika, karena matematika tidak jauh dari kehidupan yang sebenarnya, selalu memakai perhitungan dan menegenal angka-angka bahkan dalam berinteraksi tidak lepas dari matematika.

\section{METODE PENELITIAN}

Metode penelitian yang digunakan adalah metode kuantitatif dengan jenis penelitian eksperimen semu atau sering disebut eksperimen kuasi (quasi eksperimental research jenis peneliatian ini adalah pretest posttest with Nonequivalent Control Group Design tidak dilakukan pemilihan secara random melainkan dipilih dengan sengaja oleh peneliti yaitu dengan masing-masing kelas eksperimen 30 siswa dan kelas kontrol 28 siswa pada kelas III.

\section{Desain Nonequivalent Control Group}

\begin{tabular}{|l|l|c|l|}
\hline Group & Pre-test & Treatment (perlakuan) & Post-test \\
\hline EG (Eksperiment Group) & $\mathrm{O}_{1}$ & $\mathrm{X}$ & $\mathrm{O}_{2}$ \\
\hline CG (Control Group) & $\mathrm{O}_{3}$ & & $\mathrm{O}_{4}$ \\
\hline
\end{tabular}

\footnotetext{
Keterangan:
}

O1: Pre-test Eksperimen Group

O2: Post-test Eksperimen Group 


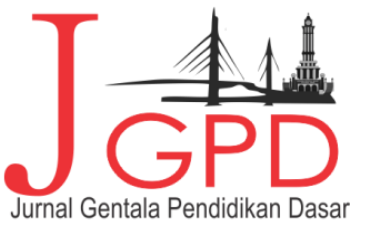

JURNAL GeNTALA PENDIDIKAN DASAR Vol.4 No 2 December 2019 Page 15I-I65 P-ISSN : 2614-7092, E-ISSN : 2621-S611

Available Online at: http://online-juurnal.unja.ac.id/index.php/gentala email : penyunting.jurnal.g-pgsd国unja.ac.id

X: Matematika Realistik

- : Konvensional

O3: Pre-test Contol Group

O4: Post-test Contol Group

Peneliti melakukan pengukuran terhadap keberadaan suatu variabel dengan menggunakan instrumen penelitian. Variabel merupakan gejala yang menjadi fokus peneliti untuk diamati. Penelitian ini menggunakan 3 (tiga) variabel, 1 variabel Bebas (X) dan 2 Variabel terikat $\left(\mathrm{Y}_{1}\right.$ dan $\left.\mathrm{Y}_{2}\right)$

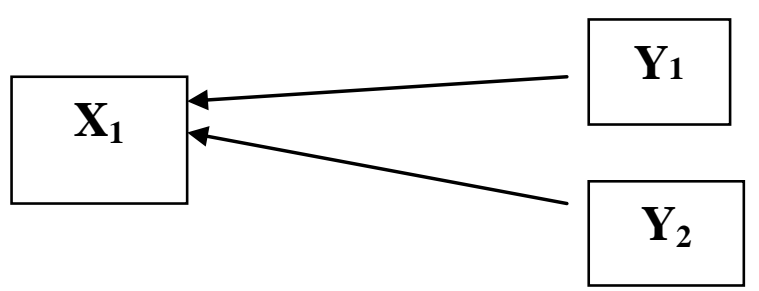

Penelitian ini dilaksanakan di SDIT Al-Madinah Cibinong Bogor tahun pelajaran 20182019. Penelitian ini mengambil subjek yaitu kelas III A berjumlah 30 siswa dan kelas III B yang berjumlah masing-masing 28 orang siswa. Teknik pengambilan data dilakukan dengan menggunakan instrumen penelitian yaitu observasi untuk mengambil data karakter jujur, test untuk mengambil data prestasi melalui pre-test dan post-test dan dokumentasi.

Metode pengumpulan data yang digunakan dalam penelitian ini adalah observasi dan tes. Instrumen yang digunakan dalam melakukan observasi adalah lembar observasi. Sedangkan untuk mengukur prestasi belajar digunakan tes. Tes yang digunakan dalam penelitian ini berupa tes tertulis dengan menggunakan materi yang memiliki tingkat yang sama dengan materi belajar pada tingkatan siswa yang menjadi sampel peneliti. Test tersebut diberikan secara 2 kali yaitu pre-test dan post-test.. Sebelum digunakan, instrumen terlebih dahulu diuji validitas dan diuji reabilitasnya.

Uji hipotesis dalam penelitian ini dilakukan melalui metode statistik dengan menggunakan formula Uji t dengan menggunakan aplikasi SPSS 20. Dalam penelitian ini dicari pengaruh pendekatan pembelajaran matematik realistik terhadap prestasi belajar dan karakter jujur. 


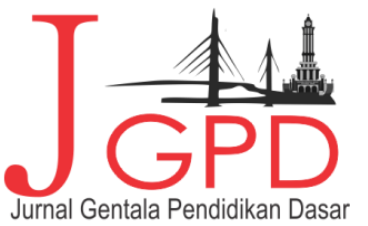

JURNAL GeNTALA PENDIDIKAN DASAR Vol.4 No 2 December 2019 Page 15I-165 P-ISSN : 2614-7092, E-ISSN : 2621-S611

Available Online at: http://online-juurnal.unja.ac.id/index.php/gentala email : penyunting.jurnal.g-pgsd国unja.ac.id

\section{HASIL PENELITIAN}

\section{Prestasi Test Kelas Eksperimen}

Berdasarkan data jumlah nilai Pre-test kelas eksperimen dengan rata-rata 64,7, sedangkan jumlah nilai Post-test kelas eksperimen dengan rata-rata 96,4. Maka dapat disimpulkan bahwa prestasi hasil belajar siswa kelas eksperimen dalam mata pelajaran matematika dengan menggunakan pendekatan matematika realistik meningkat.

\section{Prestasi Hasil Test Kelas Kontrol}

Berdasarkan data dapat diketahui bahwa nilai rata-rata pre-test dan post-test kelas kontrol mendapatkan nilai pre-test dengan rata-rata 53,7 sedangkan nilai rata-rata post-test 87,9 .

Berdasarkan data prestasi hasil belajar siswa dari kedua kelas yaitu kelas eksperimen dan kelas kontrol, dapat disimpulkan bahwa adanya perbedaan nilai rata-rata antara kelas eksperimen dan kontrol. Dapat diketahui bahwa kelas eksperimen lebih besar dan mengalami peningkatan prestasi belajar siswa dengan menggunakan pendekatan matematika realistik dibandingkan dengan kelas kontrol yang hanya mengalami peningkatan yang sedikit dalam prestasi belajar siswa. Untuk melihat hasil nyata (real).

\section{Paired Sample $t$ Test kelas Eksperimen hasil prestasi belajar}

Berdasarkan hasil perhitungan diatas dengan menggunakan Paired Sample t test dengan aplikasi SPSS 20 di kelas eksperimen, diperoleh hasil t hitung adalah --9,328 dengan (df) data frekuensi (n-1) yaitu 30-1 yaitu 29. Pengambilan keputusan melihat hasil sig. (2-tailed) adalah 0,000. Hal ini menunjukan bahwa angka tersebut lebih kecil dari 0,05. Untuk keputusan tersebut didasari oleh sig. (2-tailed) lebih kecil dari 0,05 atau Ha diterima. Maka terdapat perbedaan yang signifikan antara nilai rata-rata pre-test dan Post-test prestasi hasil belajar siswa. Sedangkan jika sig. (2-tailed) lebih besar dari 0,05 maka Ha ditolak dan Ho diterima. Dapat disimpulkan bahwa pengaruh pendekatan matematika realistik lebih signifikan terhadap prestasi belajar siswa.

\section{Paired Sample t Test kelas Kontrol hasil prestasi belajar}

Berdasarkan hasil perhitungan dengan menggunakan Paired Sample $t$ test dengan aplikasi SPSS 20 di kelas eksperimen, diperoleh hasil t hitung adalah -7,211 dengan (df) data 


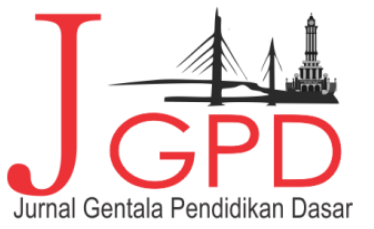

JURNAL geNTALA PENDIDIKAN DASAR Vol.4 No 2 December 2019 Page 15I-165 P-ISSN : 2614-7092, E-ISSN : 2621-9611

Available Dnline at: http://online-journal.unja.ac.id/index.php/gentala email : penyunting.jurnal.g-pgsd国unja.ac.id

frekuensi (n-1) yaitu 22-1 yaitu 23. Pengambilan keputusan melihat hasil sig. (2-tailed) adalah 0,000. Hal ini menunjukan bahwa angka tersebut lebih kecil dari 0,05. Untuk keputusan tersebut didasari oleh sig. (2-tailed) lebih kecil dari 0,05 atau Ha diterima. Maka terdapat perbedaan yang signifikan antara nilai rata-rata pre-test dan Post-test prestasi hasil belajar siswa. Sedangkan jika sig. (2-tailed) lebih besar dari 0,05 maka Ha ditolak dan Ho diterima. Terdapat perbedaan yang signifikan antara nilai rata-rata pre-test dan post-test prestasi belajar siswa.

Berdasarkan hasil perhitungan pre-test dan post-test menggunakan paired sample t test menggunakan SPSS 20 pada kelas eksperimen dan kelas kontrol, maka untuk menghitung data perbandinan antara hasil post-test kelas eksperimen dan kelas kontrol menggunakan independent sample t test dalam aplikasi SPSS 20

\section{Independent sample t test terhadap prestasi belajar siswa Antara Post-tets kelas eksperimen dan kelas kontrol}

Berdasarkan perhitungan independent sample t test pada kelas eksperimen dan kelas kontrol di peroleh hasil t hitung adalah -8,361 Pengambilan keputusan ini melihat hasil sig. (2-tailed) adalah 0,000 hal ini menunjukkan bahwa angka tersebut lebih kecil dari 0,05, keputusan tersebut didasari oleh sig. (2-tailed) lebih kecil dari 0,05 atau Ha diterima, maka terdapat perbedaan yang signifikan antara nilai rata-rata post-test kelas eksperimen dan kelas kontrol. Dapat disimpulkan bahwa terdapat peningkatan prestasi belajar siswa.

Observasi (pengamatan) dan penilaian karakter disiplin siswa dilakukan dengan mengisi lembar observasi karakter disiplin melalui pendekatan matematika realistik dan pendekatan konvensional (ceramah). Dibawah ini merupakan data deskripsi nilai karakter disiplin siswa pada kelas eksperimen dan kelas kontrol.

\section{Karakter Jujur kelas Eksperimen}

Berdasarkan data dapat diketahui bahwa jumlah nilai pre-test kelas eksperimen dengan rata-rata 15 dan rata-rata post-test 30,1. Maka dapat disimpulkan bahwa terdapat peningkatan karakter disiplin pada kelas eksperimen dengan menggunakan pendekatan matematika realistik. 


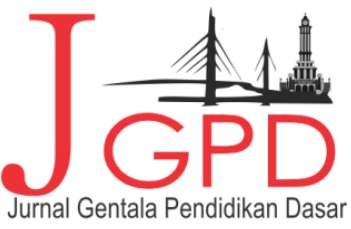

JURNAL GeNTALA PENDIDIKAN DASAR Vol.4 No 2 December 2019 Page 15I-165 P-ISSN : 2614-7092, E-ISSN : 2621-S611

Available Online at: http://online-juurnal.unja.ac.id/index.php/gentala email : penyunting.jurnal.g-pgsd国unja.ac.id

\section{Karakter Jujur kelas kontrol}

Berdasarkan data dapat diketahui nilai rata-rata pre-test dan post-test kelas kontrol dengan rata-rata nilai pre-test 11,3 dan rata-rata nilai post-test 21,3.

Berdasarkan data di atas nilai karakter jujur siswa dari kelas eksperimen dan kelas kontrol, maka dapat disimpulkan bahwa adanya perbedaan nilai rata-rata antara kedua kelas tersebut. Jika dilihat perbandingan nilai rata-rata kelas eksperimen dan kelas kontrol maka dapat diketahui bahwa nilai karakter jujur siswa kelas eksperimen mengalami peningkatan lebih besar dengan menggunakan pendekatan matematika realistik dibandingan dengan kelas kontrol yang hanya sedikit mengalami peningkatan pada karakter jujur.

\section{Pairet simple t test kelas Eksperimen hasil nilai Karakter Jujur}

Berdasarkan hasil perhitungan paired sample t test menggunakan aplikasi SPSS $20 \mathrm{di}$ kelas eksperimen, diperoleh hasil t hitung adalah -17,877dengan (df) data frekuensi (n-1) yaitu 30-1 = 29. Keputusan ini dilihat dari hasil sig. (2-tailed) adalah 0,000 hal ini menunjukkan angka tersebut lebih kecil dari 0,05. Pengambilan keputusan tersebut didasari oleh sig. (2-tailed) lebih kecil dari 0,05 atau Ha diterima. Maka terdapat perbedaan yang signifikan antara nilai rata-rata pre-test dan post-test karakter jujur. Maka dapat disimpulkan bahwa terdapat pengaruh pendekatan matematika realistik yang signifikan ter,hadap karakter jujur siswa.

\section{Paired sample t test kelas Kontrol hasil Karakter Jujur}

Berdasarkan hasil perhitungan paired sample t test menggunakan aplikasi SPSS 20 di kelas kontrol, diperoleh hasil t hitung adalah -13,746 dengan (df) data frekuensi (n-1) yaitu 23-1 = 22. Keputusan ini dilihat dari hasil sig. (2-tailed) adalah 0,000 hal ini menunjukkan angka tersebut lebih kecil dari 0,05. Pengambilan keputusan tersebut didasari oleh sig. (2tailed) lebih kecil dari 0,05 atau Ha diterima. Maka terdapat perbedaan yang signifikan antara nilai rata-rata pre-test dan post-test karakter jujur.

Berdasarkan hasil perhitungan pre-test dan post-test menggunakan paired sample t test pada kelas eksperimen dan kelas kontrol, maka untuk membandingkan data post-test dari kedua kelas tersebut menggunakan independent sample t test. 


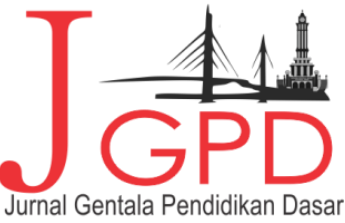

JURNAL GeNTALA PENDIDIKAN DASAR Vol.4 No 2 December 2019 Page 15I-165 P-ISSN : 2614-7092, E-ISSN : 2621-S611

Available Online at: http://online-journal.unja.ac.id/index.php/gentala email : penyunting.jurnal.g-pgsd国unja.ac.id

\section{Independent sample t test karakter Jujur}

Berdasarkan perhitungan independent sample t test pada kelas eksperimen dan kelas kontrol diperoleh hasil t hitung adalah --8,361. Pengambilan keputusan menlihat dari hasil sig. (2-tailed) adalah 0,000 hal ini menunjukan bahwa angka tersebut lebih kecil 0,05. Pengambilan keputusan ini didasari oleh sig. (2-tailed) lebih kecil dari 0,05 atau Ha diterima, maka terdapat perbedaan yang signifikan natara nilai rata-rata post-test pada kelas eksperimen dan kontrol. Dapat disimpulkan bahwa terdapat peningkatan karakter jujur.

\section{Pembahasan Prestasi Belajar Siswa dan Karakter Jujur}

Dari data-data penelitian yang telah dianalisis, diperoleh data hasil prestasi belajar siswa pada kelas eksperimen dan kelas kontrol. Dapat disimpulkan bahwa terdapat perbedaan rata-rata kedua kelas tersebut dengan nilai rata-rata kelas eksperimen pre-test 64,7 dan posttest 96,4. Sedangkan kelas kontrol mendapatkan nilai rata-rata pre-test 53,7 dan post test 87,9. dapat disimpulkan bahwa terdapat perbedaan yang signifikan antara kedua kelas tersebut dimana kelas eksperimen jauh lebih unggul dibandingkan dengan kelas kontrol. Hal tersebut karena kelas eksperimen menggunakan pendekatan matematika realistik sedangkan kelas kontrol menggunakan pendekatan konvensional (ceramah).

Pada kelas kontrol yang diberikan pembelajaran dengan menggunakan pendekatan konvensional (ceramah), pada saat pembelajaran dimulai, siswa diberikan test awal terlebih dahulu sama seperti kelas eksperimen untuk mengetahui pemahaman siswa terhadap pelajaran matematika. Sedangkan test akhir diberikan kepada siswa setelah diberikan pemahaman dan materi tentang nilai mata uang. Pendekatan konvensional hanya memberikan penjelasan materi saja yang bersifat monoton dan siswa hanya memperhatikan saja. Sehingga tujuan pembelajaran tidak tercapai sesuai dengan yang diharapkan.

Sedangkan di kelas eksperimen dengan menggunakan pendekatan matematika realistik, pada saat proses pembelajaran dimulai, sama seperti kelas kontrol siswa diberikan test awal terlebih dahulu setelah itu diberikan perlakuan dengan menggunakan pendekatan matematika realistik. Dalam pendekatan ini proses pembelajaran menggunakan permasalahan konkret (nyata) dan dapat dibayangkan oleh siswa agar siswa dapat menyelesaikan masalah dan bisa dibayangkan oleh siswa. Pendekatan matematika tidak hanya berupa masalah yang nyata namun bisa dalam bentuk permainan, penggunaan alat peraga atau lainnya selama hal tersebut dapat dibayangkan oleh siswa. 


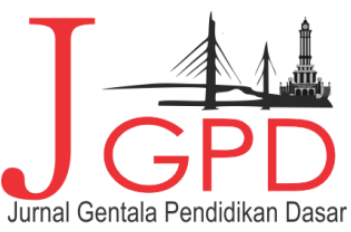

JURNAL GeNTALA PENDIDIKAN DASAR Vol.4 No 2 December 2019 Page 15I-I65 P-ISSN : 2614-7092, E-ISSN : 2621-S611

Available Online at: http://online-journal.unja.ac.id/index.php/gentala email : penyunting.jurnal.g-pgsd国unja.ac.id

Hasil pengamatan penilaian karakter jujur siswa kelas 3 SDIT Al-Madinah Cibinong Bogor yaitu kelas eksperimen dan kelas kontrol dalam kegiatan pembelajaran matematika di kelas eksperimen mengalami peningkatan dan dalam pembelajaran matematika dikelas kontrol dengan menggunakan pendekatan konvensional hanya sedikit mengalami peningkatan.

Dapat disimpulkan bahwa terdapat perbedaan nilai rata-rata pada kedua kelas tersebut dimana kelas eksperimen mendapatkan nilai rata-rata pre-test 15 dan post-test 30,1 dan kelas kontrol nilai rata-rata pre-test 11,3 dan post-test 21,3

Pengamatan dilakukan selama 4 pertemuan di kelas eksperimen dan kelas kontrol. Pada kelas kontol pertemuan pertama tidak terlihat kualifikasi tingkat jujur yang tinggi , selanjutnya pada pertemuan kedua hanya ada hanya ada beberapa siswa yang berada pada kualifikasi mulai terlihat, pada pertemuan ketiga hanya sebagian dari siswa yang mencapai kualifikasi terlihat dan sebagiannya lagi masih belum terlihat dan pada pertemuan keempat hanya $60 \%$ yang mencapai kualifikasi terlihat dan sebagiannya lagi masih pada kualifikasi belum terlihat. Artinya siswa hanya sedikit mengalami peningkatan prilaku karakter jujur

Sedangkan pada kelas eksperimen, untuk pertemuan pertama yaitu sebelum diberi perlakuan menggunakan pendekatan matematika realistik, setiap pertemuannya terdapat peningkatan yang pada awal pertemuan pertama masih belum terlihat, ketika pertemuan kedua ada beberapa siswa yang berada pada kualifikasi mulai terlihat kemudian pada pertemuan ketiga sebagian siswa mulai mengalami peningkatan dan pada pertemuan keempat setelah diberi perlakuan sesudah menggunakan pendekatan matematika realistik hampir seluruh siswa sudah mencapai kualifikasi sangat terlihat dan menjadi suatu kebiasaan siswa artinya siswa telah mengalami peningkatan prilaku yang sesuai dengan indikator jujur yang telah diamati. Selain dari karakter jujur siswa meningkat, prestasi hasil belajar siswa pun ikut meningkat.

Dengan demikian dapat disimpulkan bahwa terdapat perbedaan antara data kedua kelas tersebut dimana kelas eksperimen lebih signifikan serta lebih unggul dibandingkan dengan kelas kontrol. Hal terserbut karena kelas eksperimen mendapatkan perlakuan dengan menggunakan pendekatan matematika realistik dibandingkan dengan kelas kontrol yang hanya menggunakan pendekatan konvensional. 


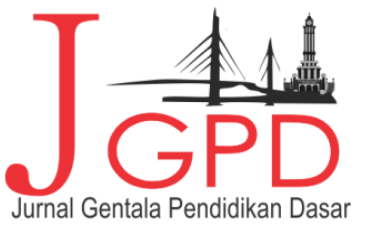

JURNAL GeNTALA PENDIDIKAN DASAR Vol.4 No 2 December 2019 Page 15I-I65 P-ISSN : 2614-7092, E-ISSN : 2621-S611

Available Online at: http://online-juurnal.unja.ac.id/index.php/gentala email : penyunting.jurnal.g-pgsd国unja.ac.id

\section{KESIMPULAN DAN IMPLIKASI}

Dari hasil penelitian dan berdasarkan sumber-sumber data yang diperoleh maka penulis dapat mengambil kesimpulan dan implikasi sebagai berikut:

1. Berdasarkan penelitian yang telah dilakukan, prestasi belajar matematika pada kelas eksperimen mendapatkan peningkatan yang sangat besar dengan menggunakan matematika realistik. Peningkatan tersebut dilihat dari hasil post-test yang meningkat dari pre-test.

2. Berbeda dengan kelas eksperimen, kelas kontrol hanya mengalami sedikit peningkatan prestasi belajar. Dikarenakan, kelas kontrol hanya menggunakan pendekatan konvensional (ceramah) yang mengakibatkan terjadinya sedikit peningkatan pada prestasi belajar.

3. Berdasarkan penelitian dan pengamatan, karakter jujur pada kelas eksperimen meningkat dari pengamatan awal pembelajaran hingga pengamatan akhir dari pembelajaran. Dalam peningkatan tersebut matematika realistik yang berpengaruh terhadap karakter jujur

4. Berbeda dengan kelas eksperimen, pengamatan pada kelas kontrol hanya mengalami sedikit peningkatan terhadap karakter jujur. Dikarenakan adanya pengaruh dari pendekatan yang tepat untuk meningkatan karakter

5. Pendekatan matematika realistik sangat berpengaruh terhadap prestasi maupun karakter jujur. Siswa lebih berpikir secara logis dan nyata serta mengajak siswa untuk ikut serta memecahkan masalah sehari-hari terutama pada proses pembelajaran matematika.

\section{DAFTAR PUSTAKA}

Astuti, Dkk. Pendekatan Matematika Realistik Terhadap Prestasi Belajar Matematika ditinjau dari Kemampuan Numerik. Jurnal Program Pascasarjana Universitas Ganesha (3). 2-3.

Chan, F. (2019). Gaya Mengajar Guru PNS dan Honorer di Sekolah Dasar Negeri 55/I Sridadi, Jambi. JURNAL INOVASI PENDIDIKAN DAN PEMBELAJARAN SEKOLAH DASAR, 3(1), 34-41.

Dewi, Yusfita Kumala. (2015).Pendidikan Karakter Dalam Pembelajaran Matematika. Jurnal Pendidikan Matematika 1(2). 117-118

Kurniawan, A. R., Noviyanti, S., \& Arsil, A. (2019). Optimasi Model Problem Based Learning Berbantuan Multimedia untuk Meningkatkan Keterampilan Kerja Tim di Sekolah Dasar. ELSE (Elementary School Education Journal): Jurnal Pendidikan dan Pembelajaran Sekolah Dasar, 3(2), 7-16.

Ratumanan, Dkk. (2016) Analisis Penguasaan Objek Matematika. Jurnal Pendidikan Matematika Raflesia. 1 (2). 146. 


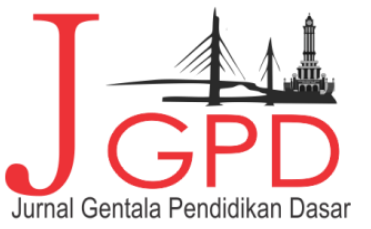

JURNAL GeNTALA PENDIDIKAN DASAR Vol.4 No 2 December 2019 Page 15I-165 P-ISSN : 2614-7092, E-ISSN : 2621-S611

Available Online at: http://online-journal.unja.ac.id/index.php/gentala email : penyunting.jurnal.g-pgsd国unja.ac.id

Shabrina, I., Rahman, I. K., \& Asmahasanah, S. (2017). Pengaruh Model Think Pair And Share Terhadap Hasil Belajar Matematika Siswa Sekolah Dasar. Jurnal Gentala Pendidikan Dasar, 2(1), 140-150. https://doi.org/10.22437/gentala.v2i1.6823

Sarbiyono, (2016). Penerapan Pendekatan Matematika Realistik Terhadap Kemampuan Pemecahan Masalah Sistematis Siswa. Jurnal Ampel Surabaya, 1 (2). 164

Sawitri, Dian Ratna \& Heri Setiawan Suhandi. (2017). Hubungan antara Adversity Intellingence dengan Motivasi Belajar dalam Mata Pelajaran Matematika Pada Siswa. Jurnal Fakultas Psikologi.6 (4). 2-3.

Sirait, Doni Erlando. (2016). Pengaruh Minat Belajar Terhadap Prestasi Belajar Matematika. Jurnal Formatif 6 (1). 36.

Supriatna, Salati A dkk. (2019). The effect of learning methods and self regulation on problem-solving ability of mathematics in elementary school The effect of learning methods and self regulation on problem-solving ability of mathematics in elementary school.

https://www.researchgate.net/publication/333654956_The_effect_of_learning_methods _and_self_regulation_on_problem-

solving ability_of mathematics_in_elementary_school The effect_of_learning metho ds_and_self_regulation_on_problem-solving_ability_of_mathe $=57209456457$. J. Phys.: Conf. Ser. 1175012139.

Taniredja, Tukiran. Dkk. (2011). Model-model Pembelajaran Inovatif. Bandung : Alfabeta

Yantoro, Y. (2017). Meningkatkan Rasa Ingin Tahu Dengan Menggunakan Metode Pemecahan Masalah Di Sekolah Dasar. Jurnal Gentala Pendidikan Dasar, 2(1), 90105. https://doi.org/10.22437/gentala.v2i1.6820 